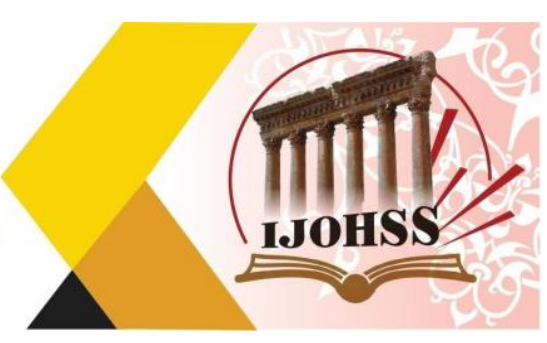

\title{
تقييم جودة بيئة رعاية الأطفال للأطفال الصغار من وجهة نظر الأمهات
}

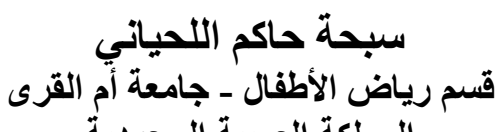

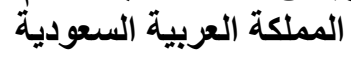

الخلفية: كان الغرض من الدراسة الحالية هو توضيح مدى أهمية بيئة رعاية الطفل المبكرة؛ كما تهدف هذه الدراسة إلى معرفة وجهة نظر الأمهات حول جودة التعليم و البيئة المحيطة في مرحلة الطفولة المبكرة في المملكة العربية السعودية. كما انه في هذه الأيام أصبحت غالبية الامهات من القوى العاملة، وبالتالي يكون لديهن وقت ولت ولته أقل مع أطفالهن. الأهمية: تبحث هذه الدراسة في وجهات نظر الأم حول تقييم جودة بيئة رعاية الأطفال الصغار.

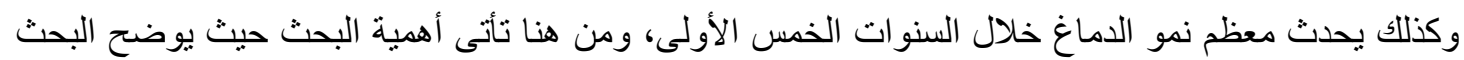
كيف أن التعليم و البيئة المحيطة في مرحلة الطفولة المبكرة يفيد الجانب المعرفي واللغوي و التنمية الاجتماعية على الددى القصير و الطويل. النتائج: كثفت نتائج هذه الدراسة أن جودة التعليم والبيئة في مرحلة الطفولة

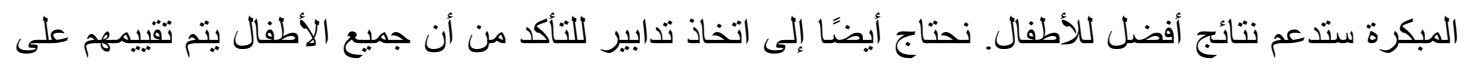

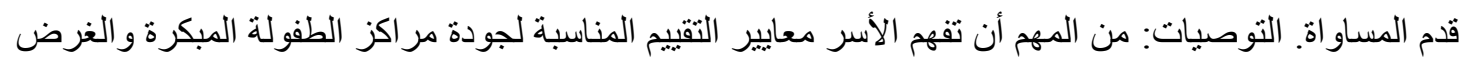
منها هو تعزيز تعلم الأطفال وتطور هم من أجل تحقيق العدالة و التميز للأطفال الدارجين. 


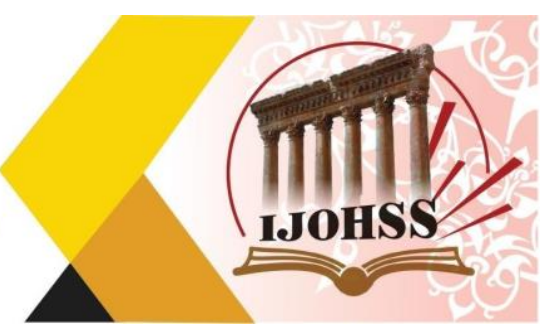

\title{
Assessing the Quality of Toddlers Child care Environment from Mothers' perspectives
}

\author{
Allehyani, Sabha Hakim \\ Department of Kindergarten -Umm Al-Qura University \\ Saudi Arabia
}

\begin{abstract}
Background: The purpose of the current study was to illustrate how important the early child care environment; this study is designed to know the mothers' perspectives about the quality of the early childhood education and environment in Saudi Arabia. As nowadays the majority of mothers is in the workforce and thus has less time with their children. Significance: This study is investigating mother's perspectives about assessing the quality of toddlers' child care environment. Most of the brain development occurs during the first five years hence the research takes its importance as the research clarify how high-quality early childhood education and environment benefits children's cognitive, language, and social development both in the short and the long term. Results: The results from this study revealed that high quality Early Childhood Education (ECE) and environment will support better children learning outcomes. Besides, we need to put measures to make sure that all children are assessed equally. Recommendation: It is crucial for families to understand the ageappropriate assessment standards that use to evaluate the quality of early childhood centres and its purpose to enhance children learning and development in order to achieve equity and excellence for all of toddlers.
\end{abstract}

Keywords: Childcare, young children, a maternal view. 


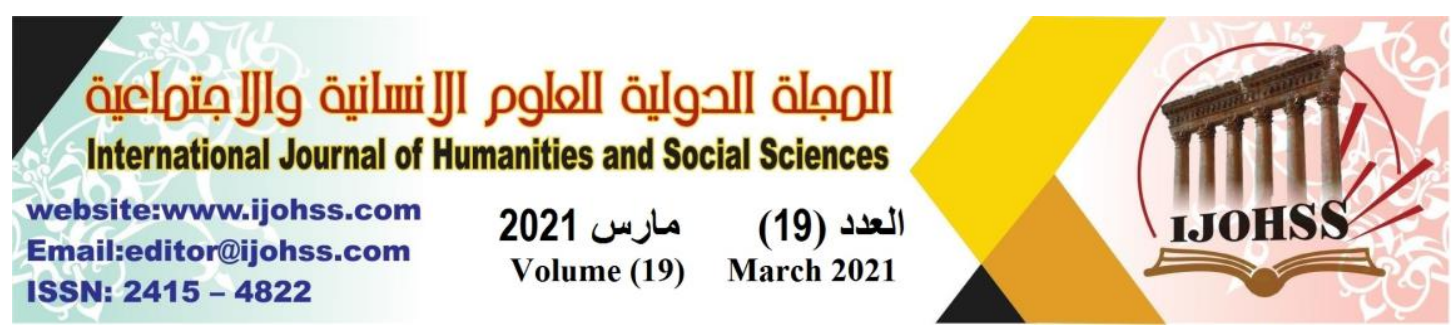

\section{Introduction}

Even though extensive empirical research has been carried out on significant impact of high-quality child care services on children development and education, few studies exists, which adequately covers disadvantaged children who do not receive enough level of care (Duncan, 2003). As a consequence, this led to attracts the worldwide attention educationally as well as economically toward improving the quality of care and education provided to all children (Mitchell, 2005). In the same context, further research by Lally (2013) revealed that there were highly increasing of the number of full working mothers in the labor force who have toddlers ages 15 to 36 months, and enrolled in center-based services, which drew the attention to the importance of providing high- level of quality in educational services in particular disadvantaged children.

Previous literature acknowledged the increased national attention in the past two decades toward early childhood classroom quality has received due to that advocates and practitioners perceive it as a crucial strategy for inspiring school readiness besides narrowing the achievement gap (Klein \& Knitzer, 2006). Recent developments in the field of classroom environment quality in ECE, which have led to a renewed interest in the high-quality educational and care environments. This might in turn be influencing children in particular toddlers to attain the developmental milestones, as the quality is found to be associated positively with infants' cognitive and language development (Burchinal, Roberts, Riggins, Zeisel, Neebe, \& Bryant, 2000). This led researchers such as Lee and Hoaken (2007) who were keen to search especially in the field of brain-based research in order to question which factors can influence the development of children's brains through their brain development and its relation to their well-being. While transformation can occur throughout infant and toddler's life most of the cognitive development occurs which empowering those children to acquire about their well resourceful classroom environment and develop social relationships between themselves and others (Lee \& Hoaken, 2007, Copple \& Bredekamp, 2009).

One of the most significant current discussions in quality standards in relation to ECE is the assessment measures, which should ensure to be suitable for all children, nevertheless of disabilities, cultural and linguistic backgrounds, and are measured equitably (Qi \& Marley, 2009). Other studies had considered the relationship between the qualifications of teachers and the high level of quality in early care and education where caregivers send quality of time working with young children (Ackerman, 2004). Recent evidence suggested that as infants can developed securely attached to their non-parental, which include caregivers or teachers via the interactive and responsive relationship throughout the day care routine (Bowlby, 2007). It has conclusively been shown that establishing consistent, nurturing, sensitive, affectionate, as well as responsive care empowers young children to maintain close 


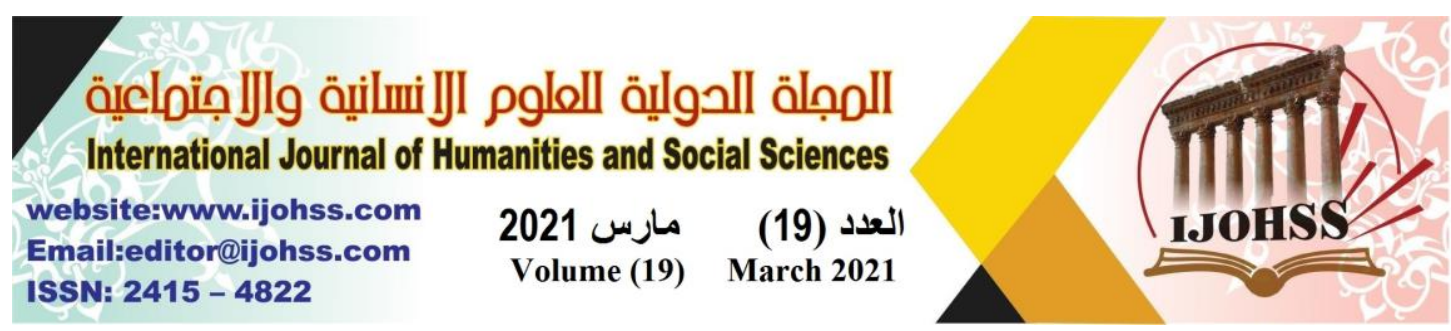

relationships with others, which develop their self-regulation, confidence to explore their environments, and influence positively on infant mental health and socialemotional development (Bronson, 2001). In the same context, similar research confirmed that healthy development of infant and toddlers physical, cognitive, emotional, social, moral and behavioral be contingent with the quality and reliability of young children's social interaction with parents and caregivers (Brazelton \& Greenspan, 2000; Edwards \& Raikes, 2002; Goleman, 2006). On the other hand, a deeper examination of the data suggested that the children of low-income families who have inadequate time to talk more with their children were reported to had lower level of language development that measured equal to their more advantaged peers (Rodriguez \& Tamis-LeMonda, 2009).

Previous research by found that high quality care is positively associated to high level of academic performance including cognitive, language, and social development (Peisner-Feinberg, Burchinal, Clifford, Howes, Kagan, Yazejian, Byler, Rustici \& Zelazo ,1999). Recent evidence suggested that young children who start the early childhood program earlier as infants and toddlers have the abilities to develop language skills at national averages by the school entry, compared to children who attend only for one or two years (Yazejian \& Bryant, 2010). There is a large volume of published studies describing the role of quality tools in assessing child care services which is a critical feature associated with the infants and toddlers' behavioral, social, and academic outcomes who attending these programs at early age (Mashburn, Pianta, Hamre, Downer, Barbarin and Bryant,2008).

One of the most significant current discussions in the field of early years is attempted to define quality of early childcare education which have indicated such core components such as teacher-child interactions, group size, adult to child ratios, and educators' level of education as significant quality standards (Rentzou \& Sakellariou 2011). Indeed, high quality childcare services and program is particularly fundamental in both day care and preschool settings which benefits young children's cognitive and social-emotional development (Sylva, Melhuish, Sammons, SirajBlatchford, \& Taggart, 2010). In recent years, there has been an increasing amount of literature on importance of infant-caregiver attachment in which many early childhood advocates and practitioners generally believe that the positive or negative interactions and transactions that infants and toddlers encounter with educators, resources, and peers are the useful means to outline and measure quality within a classroom or program (Denny et al., 2012; Early et al., 2007; Howes, Burchinal, Pianta, Pianta, Bryant, Early, Clifford \& Barbarin, 2008; Pianta et al., 2005). Empirical studies have agreed that infants and toddlers' high level of quality in relation to programs structure and routines are important because it support better children learning outcomes (Melhuish, Quinn, Sylva, Sammons, Siraj-Blatchford, \& 


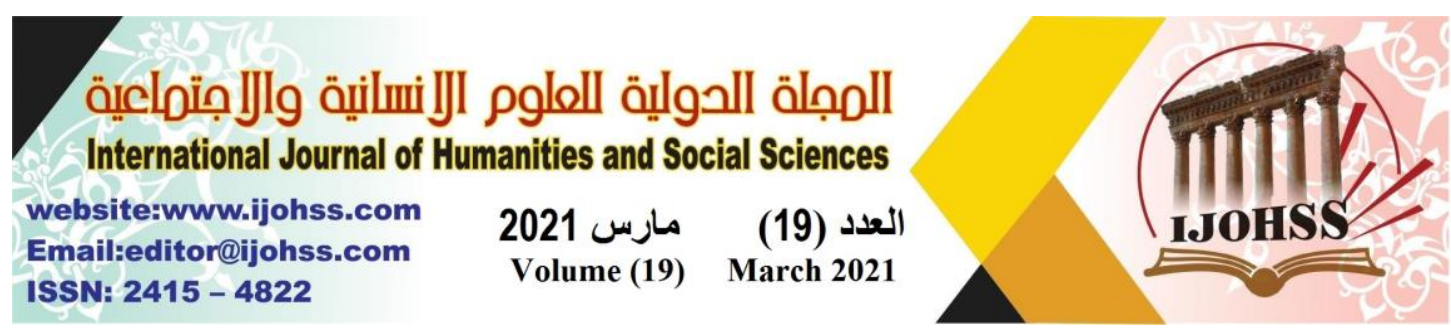

Taggart, 2012; Mashburn et al. 2008, \& Hestenes, Kintner-Duffy, Wang, La Paro, Mims, Crosby \&Cassidy, 2015).

In Western industrialized countries such as Saudi Arabia, the interest in the quality of the children learning environment increase in compliance with Saudi Arabia's Vision 2030. In Saudi Arabia, children education in particular in kindergarten stage was limited to few numbers of children and there was no assessment procedure was required. The Ministry of Education (MOE) released a decree demanding all childhood organization to apply the Quality Evaluation Tool (Gahwaji, 2006). Empirical research in the area of the evaluation of the quality of child care environment in Saudi Arabia is limited. Recent exploratory research demonstrated in Saudi Arabia by Gahwaji (2019) compared the different perspectives on quality evaluations of Saudi nurseries in public and private sectors. The main finding generated from Gahwaji's research was that the highest rating scores for the public nurseries were reported in "Personal Care Routines," "Language and Books," as well as "Space and Furnishings" in compare with the private nurseries. Social interaction between educators and young children were reported to be higher in rating score in the private nurseries (Gahwaji,2019). Consequently, it can be noted that the growing field of quality in early childhood education and care has a positive influence on Saudi childhood program quality and learning outcomes. However, there is a dearth of evidence examining the challenge for practitioners who are keen to meet parents' expectations toward achieving high-level of classroom quality for all children which need to be examined.

\section{Theoretical framework}

The definition of quality is gradually recognized as a multidimensional and problematic concept which needs to be deeply investigated in relation to age group of children in the classroom (Barnes,2001). The terms of classroom quality are often evaluated at an international level in order to measure the overall quality of a child care centre, which include structural and process aspects of classroom environment that influence the characteristics of children development and learning. The structural indicator encompasses child-to-staff ratio, group size, teachers' qualification and teaching experiences (Sabol \& Pianta, 2012). The process quality indicator refers to examine the nature of the children physical, emotional and social interactions with staff, peers and materials as well as the structural activities and aspects such as the space, program daily routines, classroom appearance, materials that support these interactions (Harms, Cryer \& Clifford, 2006). In the same context, Burchinal (2017) acknowledged that the proximal interactions among young children, adults, and the classroom materials and activities have the direct and positive impact on children's growth. Therefore, these processes and well- organized classroom structure will ensure developmentally appropriate practice for all infants and toddlers in the classroom environment. 


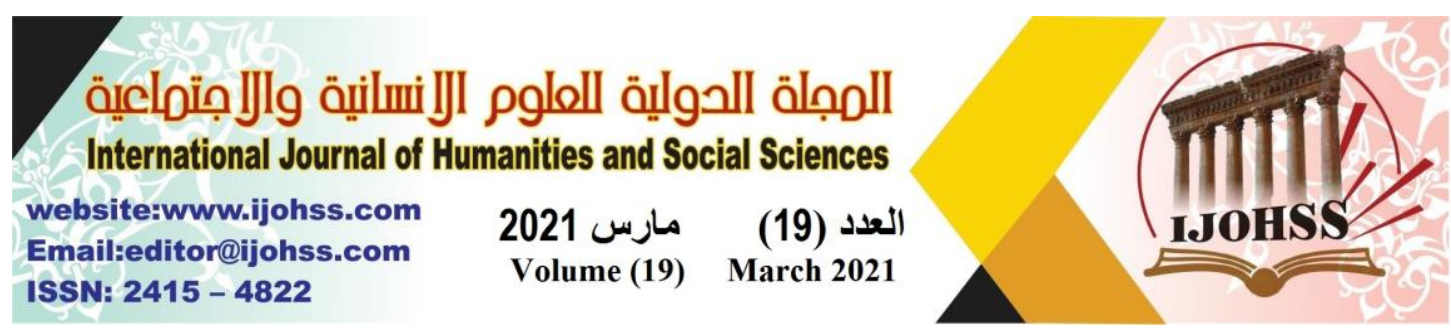

Indeed, building trust between toddlers and primary caregivers need to be established through meeting their individual needs, interest and temperament (Copple \& Bredekamp, 2009). More crucially, educators require to be responsive of the toddler's capability, willingness, and capacity for their daily social interactions. Their awareness depends on the deep understanding of the toddler's emotional needs, as well as the willingness to offer proper physical and verbal prompts in order to strengthen and protect the toddler's trust in their caregivers (Howes, James, \& Ritchie, 2003; La Paro, Williamson \& Hatfield, 2014). A large-scale research study found that positive verbal, physical, and emotional exchanges between toddlers and caregivers in child care centre serve as significant mechanisms for learning and obtaining social and emotional competence (Nelson \& Bosquet, 2000).

Furthermore, toddlers who experience higher quality child care at young ages were found to be more likely to have better learning and social outcomes (McCartney, Dearing, Taylor, \& Bub, 2007). Nonetheless, toddlers who were experienced behavior problems have a tendency to be less engaged in the classroom activities, which impacts on their engagement besides minimizes the opportunities for learning (Aguiar \& McWilliam, 2013). Thus, in conclusion, the high- level of quality classroom environment benefits toddlers' language, cognitive, , and social growth equally in the short and long term, nevertheless low- level of quality puts risks for those children (Melhuish, Ereky-Stevens, Petrogiannis, Ariescu, Penderi, Rentzou, Tawell, Leseman\& Broekhuisen, 2015).

More recently, researchers have studied the low-income children, who are living in poverty and enrolled in poor-quality child care centre experiencing double jeopardy (Watamura, Phillips, Morrissey, McCartney, \& Bub, 2011). Disadvantaged children who raised up in poor household environment were reported to experience family chaos construct, and poor parenting which we found to influence negatively their emotional and intelligent development (Watamura et al., 2011). In addition, advances in brain research gave a great insight into how young children's experiences a profound influence on genetic predispositions. This shape the processes that determine whether their brains will have adaptations or maladaptation for later cognitive skills such as memorizing, reasoning, executive functioning, and articulating a full range of positive and negative emotional behavior control (Hawley, 2000).

One of the significant indicators associated with high quality classroom environment is proper nutrition. Educators who that offered regularly scheduled periods of proper nutrition, sleep and physical activity for young children, were found to have consistent nurturing, attentive social interactions; and conscientiously buffer infant and toddlers from the adverse impacts of toxic stress such as abuse and neglect (Center on the Developing Child, 2006). The well-organized and prepared 


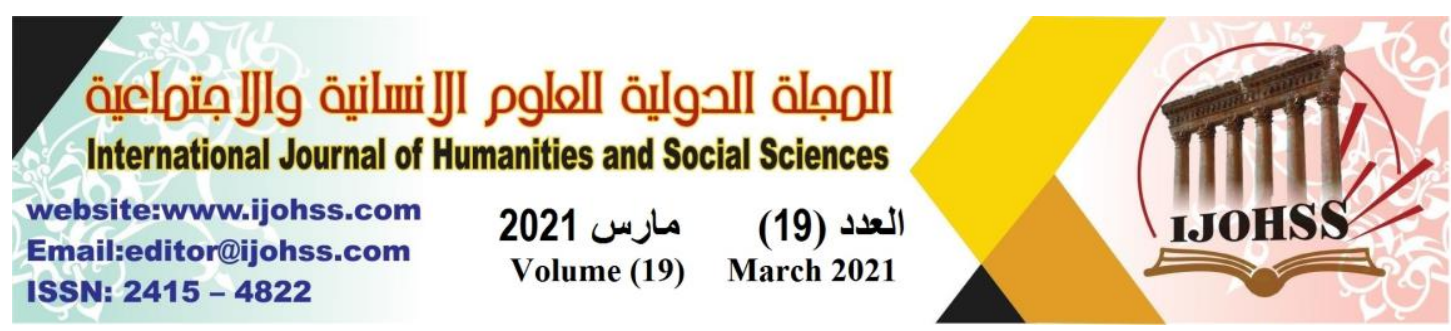

environment have greater impact on developing brain to function optimally. On the other hands, the lack of adequate nutrition, physical activity, suitable sensory stimulation and other emotional developmental practices were reported to disrupt young children brain architecture and have in turn a negative influence on their future development (Center on the Developing Child, 2006). Snow and Van Hemel (2008) asserted that assessment measures for young children classroom have to be well designed, as well as have to be implemented and interpreted effectively because they can inform teaching and contribute to better outcomes.

Additionally, play environment include indoor and outdoor areas have to contain an adequate adults' supervision of all children in order to ensures a safe learning environment as well as to support the full range of children's play activities (PeisnerFeinberg et al., 1990). However, more intensive research is needed in order to examine the validity of applying quality assessment tools such as "Infant/Toddler Classroom Pre-Coaching Quality Checklist" to assess learning and development environment of toddlers in Saudi Arabia in which the current study is tended to focus on.

\section{Methods \\ Instrument}

This research is using "Infant/Toddler Classroom Pre-Coaching Quality Checklist" which consist of nine main criteria. These criteria include (Space and Furnishings, Daily Routines, Safety Practices, Physical Development Gross and Fine Motor, Staff Interaction, Language Modeling, Facilitation of Learning, Parent Involvement, Program Structure, Teaching Strategies Gold-Related (Ts Gold-Related) and each of these criteria has sub-categories. A three-point Likert scale that ranged from (fully met), (particularly met) and (not met).

\section{Sampling}

The current data analysis includes 100 observations of toddlers' classroom environment in which "Infant/Toddler Classroom Pre-Coaching Quality Checklist" were implemented. These data were collected in three cities in the Western Region in Saudi Arabia which included the city of Jeddah, Mecca, and Taif. Participants who were aged range from one to two years old were selected randomly from different nurseries centres. These states. Further details in relation to each city's sample and data collection can be shown in Table 3 .

\section{Research Problem}

The purpose of this study was to evaluate the quality of toddlers' classroom environment using "Infant/Toddler Classroom Pre-Coaching Quality Checklist" rating scale across subgroups of 100 young children aged 1-2 years in Western Region. The analyses are designed to answer the following research question: What the Saudi 


\section{المجلة المولية اللهلوم الأنسانية والإمتاعية International Journal of Humanities and Social Sciences}

website:www.ijohss.com

Email:editor@ijohss.com

ISSN: $2415-4822$
العداد (19)

Volume (19) March 2021

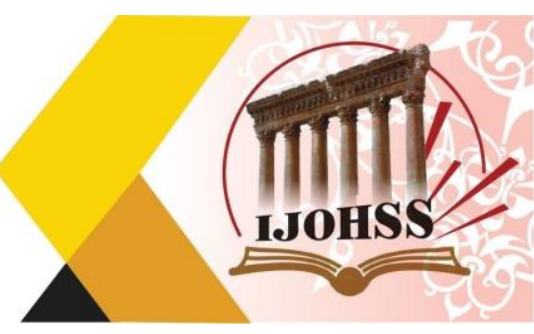

mothers' perspectives toward the quality of toddlers' classroom environment in the Western Region?

\section{Reliability and Validity \\ Questionnaire validity}

The current study examining mother's perspectives toward the quality of their toddlers' classroom environment using translated "Infant/Toddler Classroom PreCoaching Quality Checklist" rating scale. This checklist tool adapted from Early Childhood Environment Rating Scale (ITERS), Teaching Strategies GOLD (Ts GoldRelated), CLASS, Louisiana Birth to Five Early Learning Standards and NAEYC Standards. Means the ability of the questionnaire to measure what they were supposed to measure.

\section{Internal validity}

Validity was calculated using internal validity by calculating the correlation coefficient (Pearson correlation coefficient) between the score of each statement and the total score of the questionnaire. The validity using internal consistency between the total score for each axis and the total score of the questionnaire. In addition, the validity was calculated using internal consistency by calculating the correlation coefficient (Pearson Correlation Coefficient) between the total score for each axis (Space and Furnishings, Daily Routines, Safety Practices, Physical Development Gross and Fine Motor, Staff Interaction, Language Modeling, Facilitation of Learning, Parent Involvement, Program Structure, Teaching Strategies Gold-Related (Ts Gold-Related) and the overall score of the questionnaire. The Ts Gold-Related defined as an authentic observation-based assessment system for young children from (0-8 years). The following table shows that.

Table 1.

Correlation coefficients values between the degree of each statement and the degree of the questionnaire

\begin{tabular}{l|l|l}
\hline & Correlations & Sig \\
\hline Space and Furnishings & 0.883 & 0.01 \\
\hline Daily Routines & 0.712 & 0.01 \\
\hline Safety Practices & 0.927 & 0.01 \\
\hline Physical Development Gross and Fine Motor & 0.891 & 0.01 \\
\hline Staff Interaction, Language Modeling & 0.846 & 0.01 \\
\hline Facilitation of Learning & 0.953 & 0.01 \\
\hline Parent Involvement & 0.774 & 0.01 \\
\hline Program Structure & 0.801 & 0.01 \\
\hline Ts Gold-Related & 0.756 & 0.01 \\
\hline & &
\end{tabular}




\section{المجلة اللحولية اللملوم الآنسانية والإمتماعية International Journal of Humanities and Social Sciences}

website:www.ijohss.com Email:editor@ijohss.com

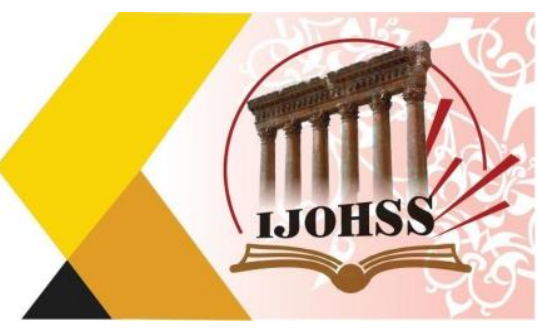

As displayed in table above that all correlation coefficients are significant at the level of (0.01) for their proximity to number one, which indicates the validity and homogeneity of the axes of the questionnaire.

\section{Reliability}

The term reliability refers to the accuracy of the test in the measurement and observation, its inconsistency with itself, its consistency and frequency in the information it provides about the behavior of the examinee, and it's the ratio between the degree variation on the scale indicating the actual performance of the examinees, and reliability is calculated by:

1- Cronbach's Alpha Coefficient

2-Split-half method

Table 2.

The values of the reliability coefficient for the questionnaire axes

\begin{tabular}{l|l|l}
\hline & Cronbach's Alpha & Split-half \\
\hline Space and Furnishings & 0.743 & $0.711-0.777$ \\
\hline Daily Routines & 0.875 & $0.842-0.909$ \\
\hline Safety Practices & 0.934 & $0.908-0.961$ \\
\hline Physical Development Gross and Fine Motor & 0.733 & $0.705-0.768$ \\
\hline Staff Interaction, Language Modeling & 0.861 & $0.835-0.890$ \\
\hline Facilitation of Learning & 0.792 & $0.766-0.823$ \\
\hline Parent Involvement & 0.774 & $0.741-0.808$ \\
\hline Program Structure & 0.812 & $0.789-0.845$ \\
\hline Ts Gold-Related & 0.911 & $0.883-0.942$ \\
\hline Reliability of the overall questionnaire & 0.859 & $0.824-0.886$ \\
\hline
\end{tabular}

As can be shown from the previous table that all the values of reliability coefficients: Alpha Coefficient, Split-half are significant at the level of (0.01), which indicates the consistency of the questionnaire.

\section{Results and Discussions Space and Furnishings}

There are statistically significant differences in the Space and Furnishings variable between the mean scores in the Quality of Toddlers Classroom Environment in the cities of Jeddah, Mecca and Taif. To verify this hypothesis, ANOVA were calculated to the mean scores in the Quality of Toddlers Classroom Environment in the cities of Jeddah, Mecca, and Taif, in relation to the Space and Furnishings variable, and the following tables illustrate that. 


\section{المجلة الحولية للعلوم الأنسانية والإمتماعية International Journal of Humanities and Social Sciences}

website:www.ijohss.com

Email:editor@ijohss.com

مارس 2021

(19) العداد

ISSN: $2415-4822$

Volume (19) March 2021

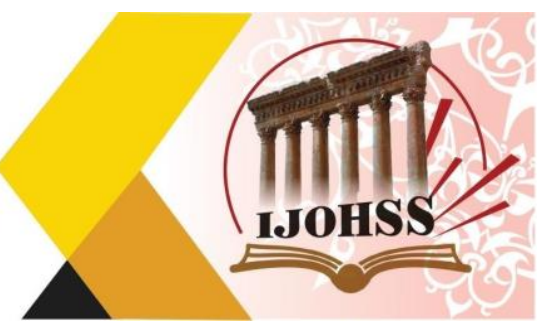

Table 3.

Analysis of variance of mean scores in Quality of Toddlers Classroom Environment in "Jeddah, Mecca, Taif" according to the Space and Furnishings variable

\begin{tabular}{l|l|l|l|l|l}
$\begin{array}{l}\text { Space and } \\
\text { Furnishings }\end{array}$ & $\begin{array}{l}\text { Sum } \\
\text { Squares }\end{array}$ & Mean Square & df & F & Sig \\
\hline Between Groups & 2934.161 & 1467.080 & 2 & 34.135 & 0.01 \\
\hline Within Groups & 4168.919 & 42.979 & 97 & & \\
\hline Total & 7103.080 & & 99 & & \\
\hline
\end{tabular}

In table 3, it is evident that the value of (F) was (34.135), which is a statistically significant value at the level of (0.01), indicating that there are differences between the degrees in the Quality of Toddlers Classroom Environment in the cities of Jeddah, Mecca, and Taif in relation to the Space and Furnishings variable, and to find out the significance trend, Scheffe's test was applied for multiple comparisons. The following table shows that.

Table 4.

Scheffe's test for multiple comparisons

\begin{tabular}{l|l|l|l}
\hline Space and Furnishings & Jeddah & Mecca & Taif \\
& $\mathrm{M}=46.329$ & $\mathrm{M}=31.258$ & $\mathrm{M}=29.014$ \\
\hline Jeddah & - & & \\
\hline Mecca & $* * 15.071$ & - & \\
\hline Taif & $* * 17.315$ & $* 2.244$ & -
\end{tabular}

Space and Furnishings

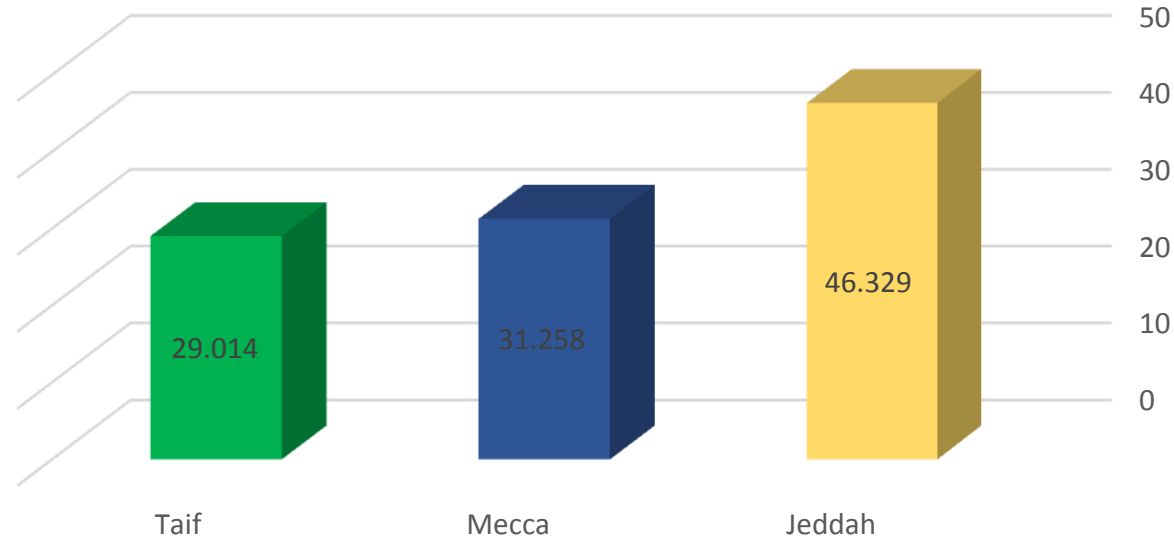

Figure 1. score differences in Quality of Toddlers Classroom Environment In "Jeddah, mecca, Taif", according to the variable Space and Furnishings variable 


\section{المجلة اللحولية اللملوم الآنسانية والإمتماعية International Journal of Humanities and Social Sciences}

website:www.ijohss.com Email:editor@ijohss.com

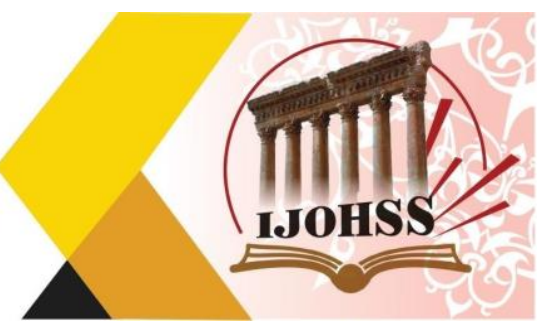

As showed in table (4) and figure (1) above that there are differences in Space and Furnishings between Jeddah and both Taif and Mecca in favor of Jeddah at a significance level (0.01), while there are differences between Mecca and Taif in favor of Mecca at a significance level (0.05). Also, where the average score of Jeddah (46.329), followed by Mecca with an average (31.258), followed by Taif with an average (29.014), so Jeddah comes first, then Mecca in second place, and finally Taif in last place.

\section{Daily Routines}

In relation to the daily routines' variable, there are statistically significant differences between the mean scores in the Quality of Toddlers Classroom Environment in Jeddah, Mecca, and Taif. To verify this hypothesis, ANOVA were calculated to the mean scores in the Quality of Toddlers Classroom Environment in the cities of Jeddah, Mecca, and Taif, in regard to daily routines variable, and the following tables illustrate that.

Table 5.

Analysis of variance of mean scores in Quality of Toddlers Classroom Environment in "Jeddah, Mecca, and Taif" according to Daily Routines variable

\begin{tabular}{l|l|l|l|l|l}
\hline Daily Routines & $\begin{array}{l}\text { Sum } \\
\text { Squares }\end{array}$ & Mean Square & df & F & Sig \\
\hline Between Groups & 3090.359 & 1545.179 & 2 & 56.003 & \multirow{2}{*}{0.01} \\
\hline Within Groups & 2676.312 & 27.591 & 97 & & \\
\hline Total & 5766.671 & & 99 & & \\
\hline
\end{tabular}

It is clear from the table (5) that the value of $(\mathrm{F})$ was (56.003), which is a statistically significant value at the level of (0.01), indicating that there are differences between the degrees in the quality of toddlers classroom environment in the cities of Jeddah, Mecca, and Taif in relation to daily routines variable, and to find out the significance trend, Scheffe's test was applied for multiple comparisons. The following table shows that.

Table 6.

Scheffe's test for multiple comparisons

\begin{tabular}{l|l|l|l}
\hline Daily Routines & Jeddah & Mecca & Taif \\
& $\mathrm{M}=37.225$ & $\mathrm{M}=30.124$ & $\mathrm{M}=21.247$ \\
\hline Jeddah & - & & \\
\hline Mecca & $* * 7.101$ & - & \\
\hline Taif & $* * 15.978$ & $* * 8.877$ & - \\
\hline
\end{tabular}




\section{المجلة اللحولية اللعلوم الأسانسية والإمتصاعية \\ International Journal of Humanities and Social Sciences}

website:www.ijohss.com

Email:editor@ijohss.com

مارس 2021

العداد (19)

ISSN: $2415-4822$

Volume (19) March 2021
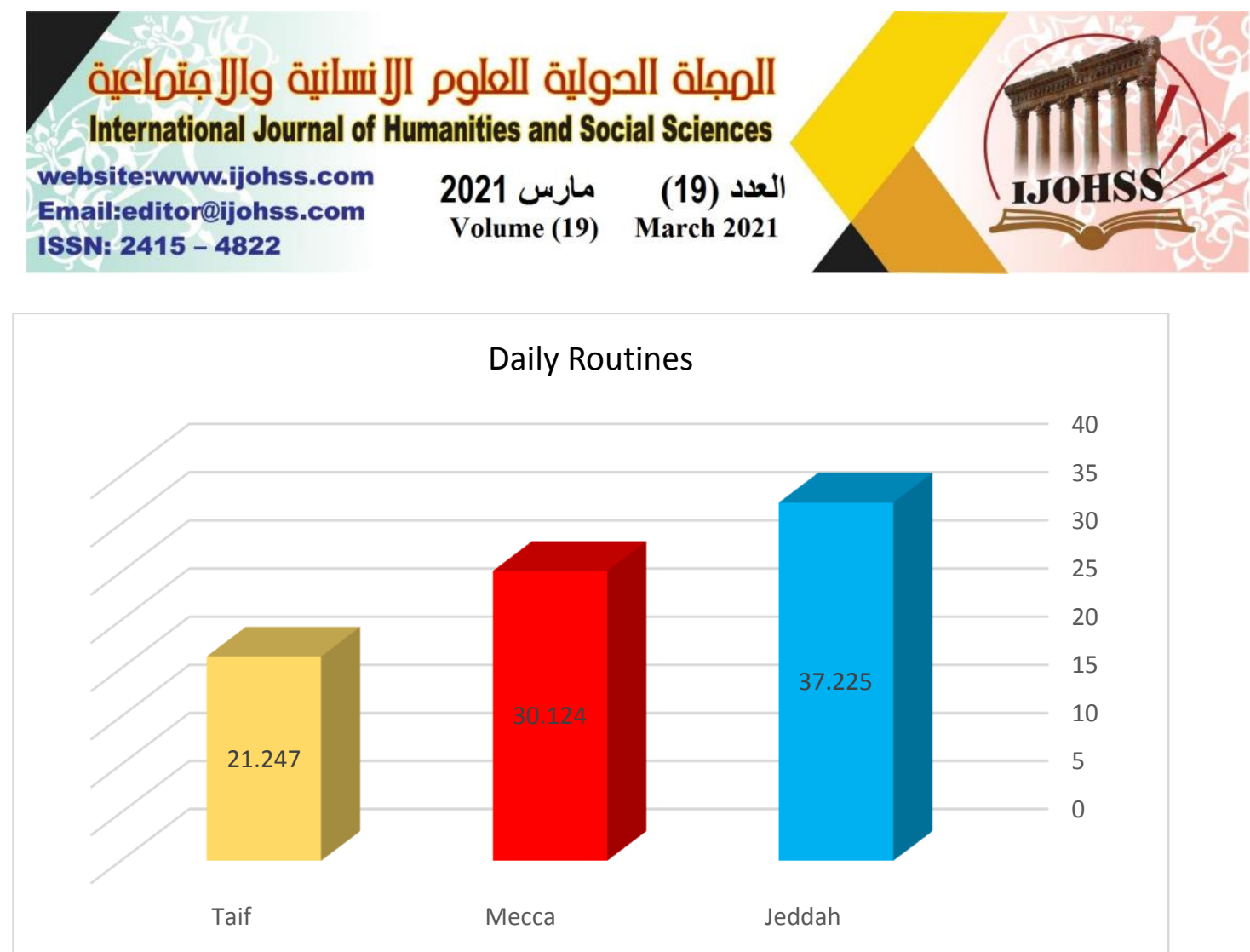

Figure 2. Score differences in Quality of Toddlers Classroom Environment In "Jeddah, Mecca, and Taif", according to daily routines variable

It is clear from the table (6) and the figure (2) that there are differences in daily routines between Jeddah and both Taif and Mecca in favor of Jeddah at a significance level (0.01), while there are differences between Mecca and Taif in favor of Mecca at a significance level (0.01), where the average score of Jeddah (37.225), followed by Mecca with an average (30.124), followed by Taif with an average (21.247), therefore Jeddah comes first, then Mecca in second place, and finally Taif in last place.

\section{Safety Practices}

There are statistically significant differences between the mean scores in the Quality of Toddlers Classroom Environment in the cities of Jeddah, Mecca, and Taif, according to Safety practices variable. To verify this hypothesis, ANOVA were calculated to the mean scores in the quality of toddlers' classroom environment in the cities of Jeddah, Mecca, and Taif, according to safety practices variable, and the following tables reveal that.

Table 7.

Analysis of variance of mean scores in Quality of Toddlers Classroom Environment in "Jeddah, Mecca, and Taif" according to Safety practices variable

\begin{tabular}{l|l|l|l|l|l}
\hline Safety Practices & $\begin{array}{l}\text { Sum of } \\
\text { Squares }\end{array}$ & Mean Square & Df & F & Sig \\
\hline Between Groups & 2882.078 & 1441.039 & 2 & 29.355 & 0.01 \\
\hline Within Groups & 4761.741 & 49.090 & 97 & & \\
\hline
\end{tabular}




\section{المجلة اللدولية اللعلوم الأسانية والإمتصاعية}

International Journal of Humanities and Social Sciences website:www.ijohss.com Email:editor@ijohss.com

مارس 2021

(19) العداد

ISSN: $2415-4822$

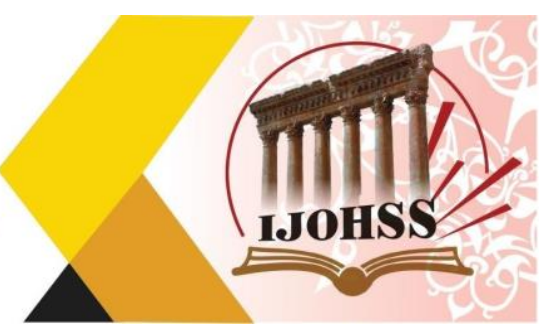

Total 7643.819 99

Table (7) demonstrated that the value of (F) was (29.355), which is a statistically significant value at the level of (0.01), indicating that there are differences between the degrees in the quality of toddlers classroom environment in the cities of Jeddah, Mecca, and Taif according to safety practices variable, and to find out the significance trend, Scheffe's test was applied for multiple comparisons (see table 8 below).

Table 8.

Scheffe's test for multiple comparisons

\begin{tabular}{l|l|l|l}
\hline Safety Practices & Jeddah & Mecca & Taif \\
& $\mathrm{M}=52.684$ & $\mathrm{M}=50.010$ & $\mathrm{M}=47.934$ \\
\hline Jeddah & - & & \\
\hline Mecca & $* 2.674$ & - & \\
\hline Taif & $* * 4.750$ & $* 2.076$ & - \\
\hline
\end{tabular}

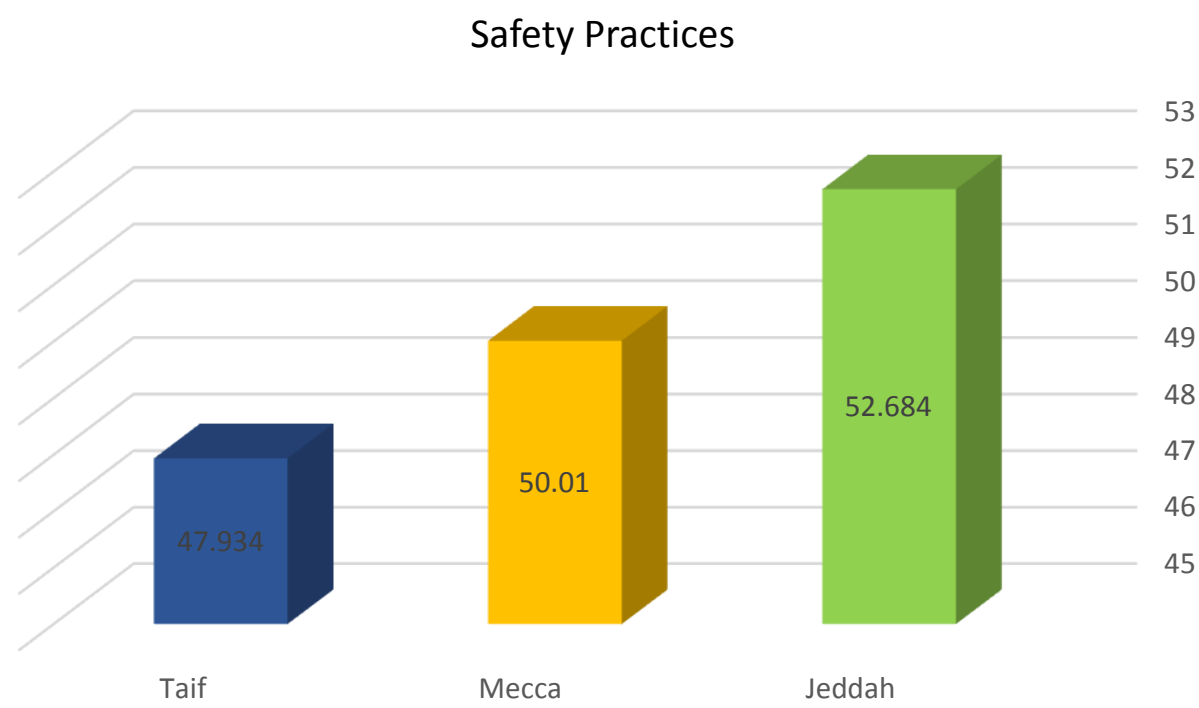

Figure 3. Score differences in Quality of Toddlers Classroom Environment In "Jeddah, Mecca, and Taif", according to Safety Practices variable

As illustrated in table (8) and figure (3) above that there are differences in Safety Practices between Jeddah and Mecca in favor of Jeddah at a significance level (0.05), while there are differences between Jeddah and Taif in favor of Jeddah at a significant level (0.01), while there are differences between Mecca and Taif in favor of Mecca at the level of Significance (0.05). The average score for Jeddah is (52.684), followed by Mecca with an average (50.010), and the city of Taif with an average (47.934). 


\section{المجلة اللدولية اللعلوم الآسانية والإمتماعية International Journal of Humanities and Social Sciences}

website:www.ijohss.com

Email:editor@ijohss.com

مارس 2021

(19) (لعدا

ISSN: $2415-4822$

Volume (19) March 2021

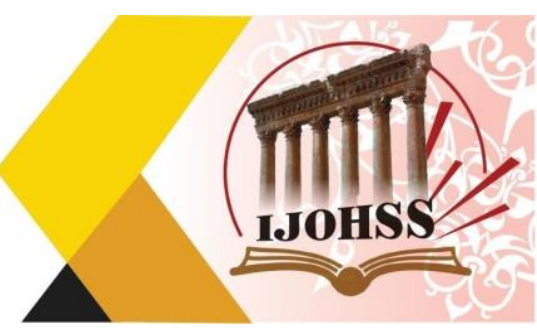

Consequently, the quality of toddlers' classroom environment in the city of Jeddah comes first, then Mecca in second place. The total score of classroom environment in the city of Taif was in last place.

\section{Physical Development Gross and Fine Motor}

There are statistically significant differences between the mean scores in the Quality of Toddlers Classroom Environment in the cities of Jeddah, Mecca, and Taif, in regard to Physical Development Gross and Fine Motor variable. To verify this hypothesis, ANOVA were calculated to the mean scores in the Quality of Toddlers Classroom Environment in Jeddah, Mecca, and Taif, according to Physical Development Gross and Fine Motor variable, and the following tables illustrate that.

Table 9.

Analysis of variance of mean scores in Quality of Toddlers Classroom Environment in "Jeddah, Mecca, and Taif" according to Physical Development Gross and Fine Motor variable

\begin{tabular}{l|l|l|l|l|l}
\hline $\begin{array}{l}\text { Physical } \\
\text { Development Gross } \\
\text { and Fine Motor }\end{array}$ & $\begin{array}{l}\text { Sum } \\
\text { Squares }\end{array}$ & Mean Square & Df & F & Sig \\
\hline Between Groups & 2995.607 & 1497.804 & 2 & 41.131 & 0.01 \\
\hline Within Groups & 3532.294 & 36.415 & 97 & & \\
\hline Total & 6527.901 & & 99 & & \\
\hline
\end{tabular}

In table (9) the value of (F) was (41.131), which is a statistically significant value at the level of (0.01), indicating that there are differences between the degrees in the quality of toddlers classroom environment in the cities of Jeddah, Mecca, and Taif according to Physical Development Gross and Fine Motor variable, and to find out the significance trend, Scheffe's test was applied for multiple comparisons. The following table shows that.

Table 10.

Scheffe's test for multiple comparisons

\begin{tabular}{l|l|l|l}
\hline Physical Development & Jeddah & Mecca & Taif \\
Gross and Fine Motor & $\mathrm{M}=14.288$ & $\mathrm{M}=10.027$ & $\mathrm{M}=6.115$ \\
\hline Jeddah & - & & \\
\hline Mecca & $* * 4.261$ & - & \\
\hline Taif & $* * 8.173$ & $* * 3.912$ & - \\
\hline
\end{tabular}




\section{المجلة اللحولية اللعلوم الأسانسية والإمتماعية International Journal of Humanities and Social Sciences}

website:www.ijohss.com Email:editor@ijohss.com مارس 2021 (19) العدا ISSN: $2415-4822$
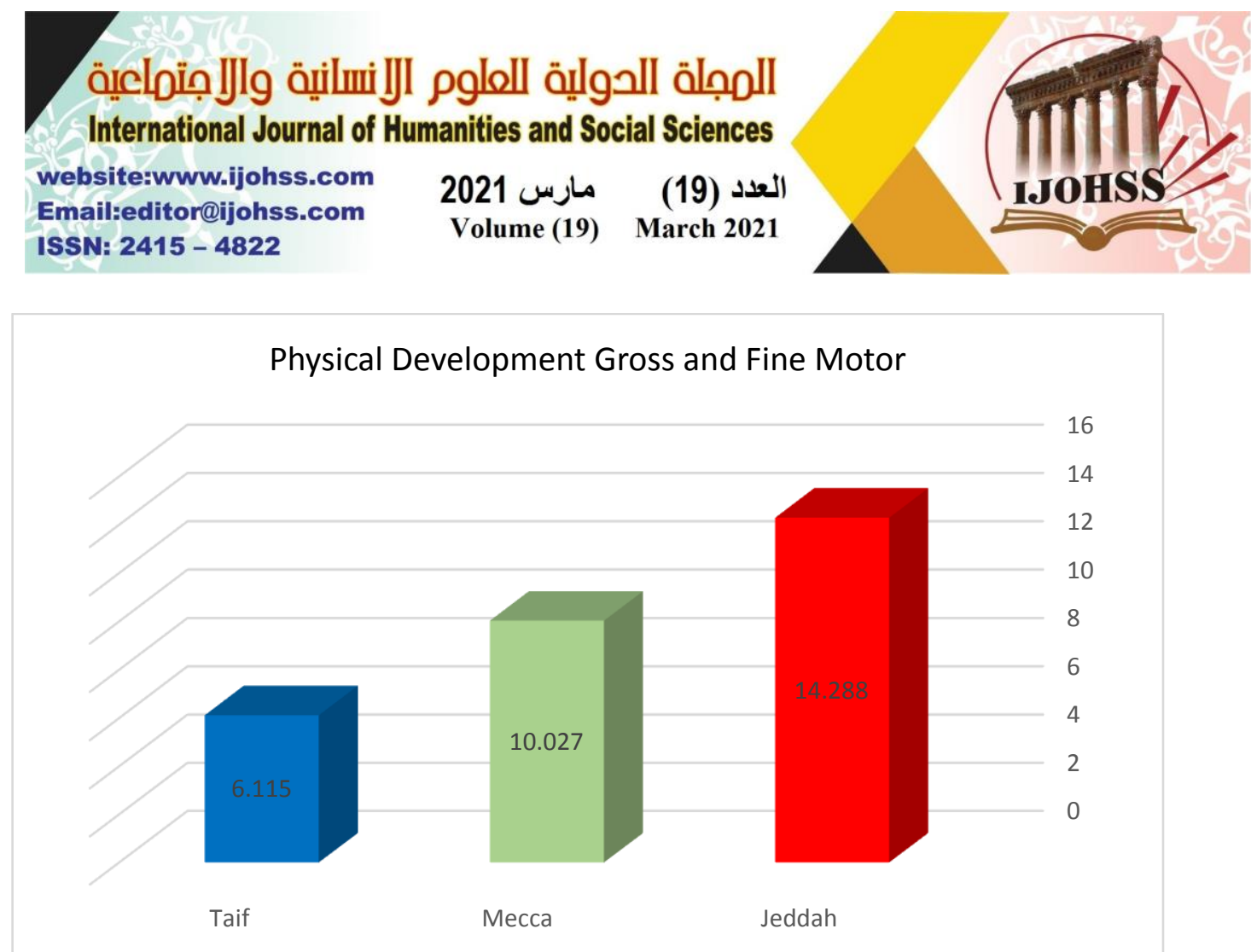

Figure 4. Score differences in Quality of Toddlers Classroom Environment In "Jeddah, mecca, Taif", according to Physical Development Gross and Fine motor variable

In Table 10 and figure 4, there are differences in Physical Development Gross and Fine Motor between Jeddah and both Taif and Mecca in favor of Jeddah at a significance level (0.01), and there are also differences between Mecca and Taif in favor of Mecca at a significance level (0.01). Where the average score for Jeddah (14.288), followed by Mecca with an average (10.027), followed by Taif with an average (6.115). Thus, it can be shown that the quality of toddlers' classroom environment in the city of Jeddah comes first, followed by Mecca in second place, and finally Taif in last place.

\section{Staff Interaction and Language Modeling}

There are statistically significant differences between the mean scores in the Quality of Toddlers Classroom Environment in Jeddah, Mecca, Taif, in relation to Staff Interaction and Language Modeling variable. To verify this hypothesis, ANOVA were calculated to the mean scores in the Quality of Toddlers Classroom Environment in the cities of Jeddah, Mecca, and Taif according to Staff Interaction, Language Modeling variable, and the following tables illustrate that.

Table 11.

Analysis of variance of mean scores in Quality of Toddlers Classroom Environment in "Jeddah, Mecca, and Taif" according to Staff Interaction, Language Modeling variable

\begin{tabular}{ll|lr|l|l|l|l}
\hline Staff Interaction, & Sum & of & Mean Square & df & F & Sig
\end{tabular}




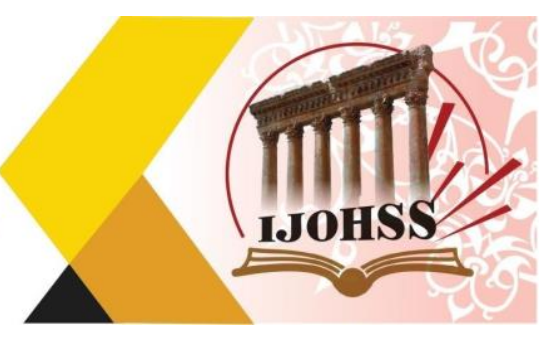

\begin{tabular}{l|l|l|l|l|l}
\hline $\begin{array}{l}\text { Language } \\
\text { Modeling }\end{array}$ & Squares & & & & \\
\hline Between Groups & 2915.956 & 1457.978 & 2 & 32.359 & 0.01 \\
\hline Within Groups & 4370.455 & 45.056 & 97 & & \\
\hline Total & 7286.411 & & 99 & & \\
\hline
\end{tabular}

As demonstrated in table (11) that the value of $(\mathrm{F})$ was (32.359), which is a statistically significant value at the level of (0.01), indicating that there are differences between the degrees in the quality of toddlers classroom environment in the cities of Jeddah, Mecca, and Taif according to Staff Interaction, Language Modeling variable, and to find out the significance trend, Scheffe's test was applied for multiple comparisons. The table 12 below shows that.

Table 12.

Scheffe's test for multiple comparisons

\begin{tabular}{l|l|l|l}
\hline Staff Interaction, & Jeddah & Mecca & Taif \\
Language Modeling & $\mathrm{M}=49.935$ & $\mathrm{M}=36.624$ & $\mathrm{M}=34.001$ \\
\hline Jeddah & - & & \\
\hline Mecca & $* * 13.311$ & - & \\
\hline Taif & $* * 15.934$ & $* 2.623$ & - \\
\hline
\end{tabular}

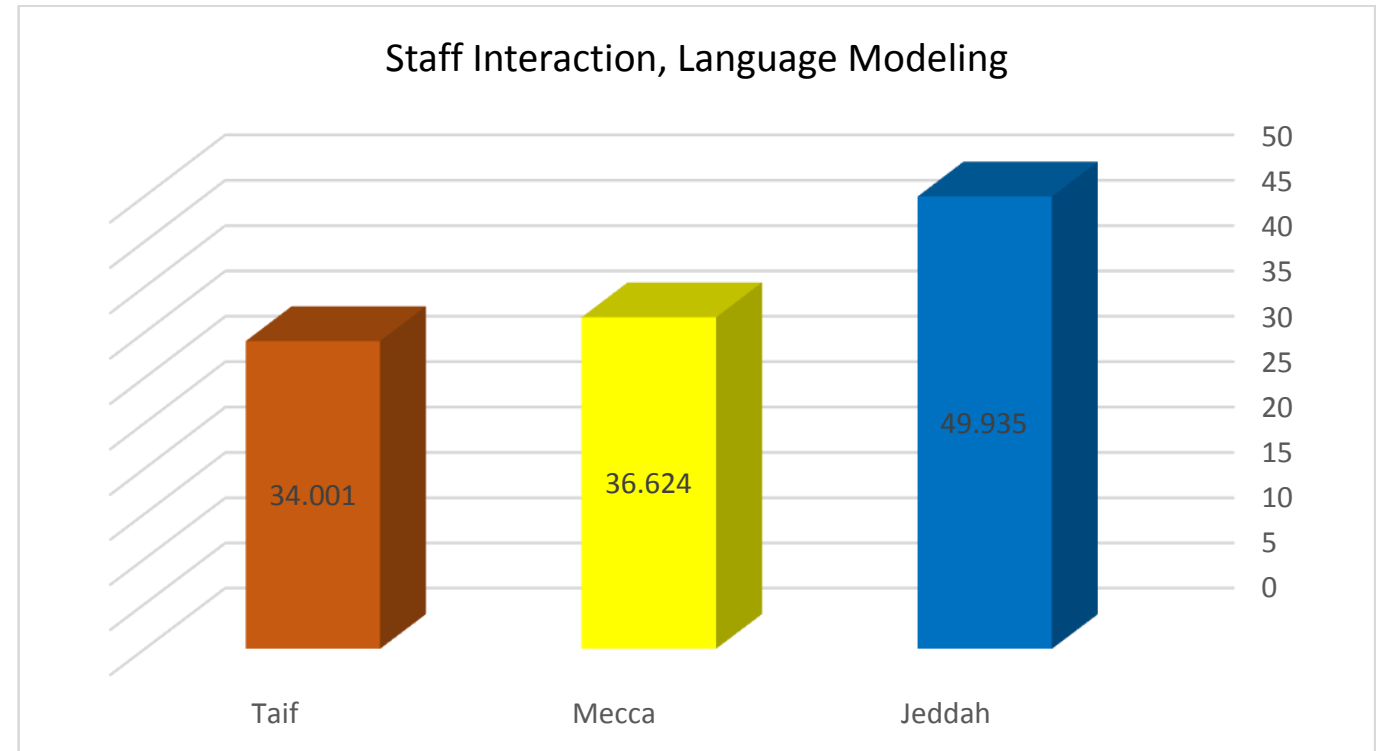

Figure 5. Score differences in Quality of Toddlers Classroom Environment In "Jeddah, Mecca, and Taif", according to Staff Interaction, Language Modeling variable 


\section{المجلة اللحولية اللملوم الآنسانية والإمتماعية International Journal of Humanities and Social Sciences}

website:www.ijohss.com Email:editor@ijohss.com

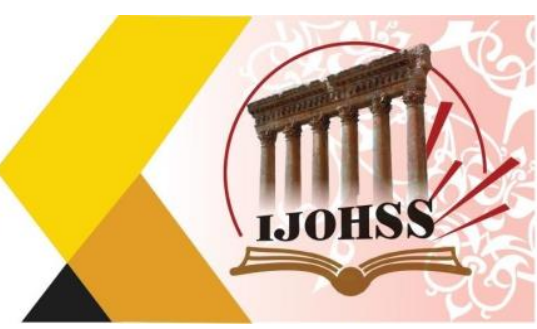

As revealed in the table (12) and the figure (5) that there are differences in Staff Interaction, Language Modeling between Jeddah and both of (Taif, Mecca) in favor of Jeddah at a significance level (0.01), while there are differences between Mecca and Taif in favor of Mecca at a significance level (0.05). The average score for Jeddah is (49.935), followed by Mecca with an average $(36,624)$, followed by Taif with an average (34.001). As a result, the quality of toddlers' classroom environment according to Staff Interaction, Language Modeling variable in the city of Jeddah comes first, followed by Mecca in second place, and lastly Taif in last place.

\section{Facilitation of Learning}

There are statistically significant differences between the mean scores in the Quality of Toddlers Classroom Environment in Jeddah, Mecca, Taif, according to Facilitation of Learning variable. To verify this hypothesis, ANOVA were calculated to the mean scores in the Quality of Toddlers Classroom Environment in the cities of Jeddah, Mecca, and Taif in relation to Facilitation of Learning variable, and the following tables illustrate that.

Table 13.

Analysis of variance of mean scores in Quality of Toddlers Classroom Environment in "Jeddah, Mecca, Taif" according to Facilitation of Learning variable

\begin{tabular}{l|l|l|l|l|l}
\hline $\begin{array}{l}\text { Facilitation of } \\
\text { Learning }\end{array}$ & $\begin{array}{l}\text { Sum } \\
\text { Squares }\end{array}$ & Mean Square & Df & F & Sig \\
\hline Between Groups & 2960.612 & 1480.306 & 2 & 36.944 & 0.01 \\
\hline Within Groups & 3886.726 & 40.069 & 97 & & \\
\hline Total & 6847.338 & & 99 & & \\
\hline
\end{tabular}

As shown in the table (13) above that the value of (F) was (36.944), which is a statistically significant value at the level of (0.01), indicating that there are differences between the degrees in the Quality of Toddlers Classroom Environment in the cities of Jeddah, Mecca, and Taif according to Facilitation of Learning variable, and to find out the significance trend, Scheffe's test was applied for multiple comparisons. The following table shows that:

Table 14.

Scheffe's test for multiple comparisons

\begin{tabular}{l|l|l|l}
\hline Facilitation of Learning & Jeddah & Mecca & Taif \\
& $\mathrm{M}=32.299$ & $\mathrm{M}=21.473$ & $\mathrm{M}=19.125$ \\
\hline Jeddah & - & & \\
\hline Mecca & $* * 10.826$ & - & \\
\hline Taif & $* * 13.174$ & $* 2.348$ & - \\
\hline
\end{tabular}




\section{المجلة اللحولية اللملوم الآنسانية والإمتماعية \\ International Journal of Humanities and Social Sciences}

website:www.ijohss.com

Email:editor@ijohss.com

مارس 2021

(19) (لعدا

ISSN: $2415-4822$

Volume (19) March 2021
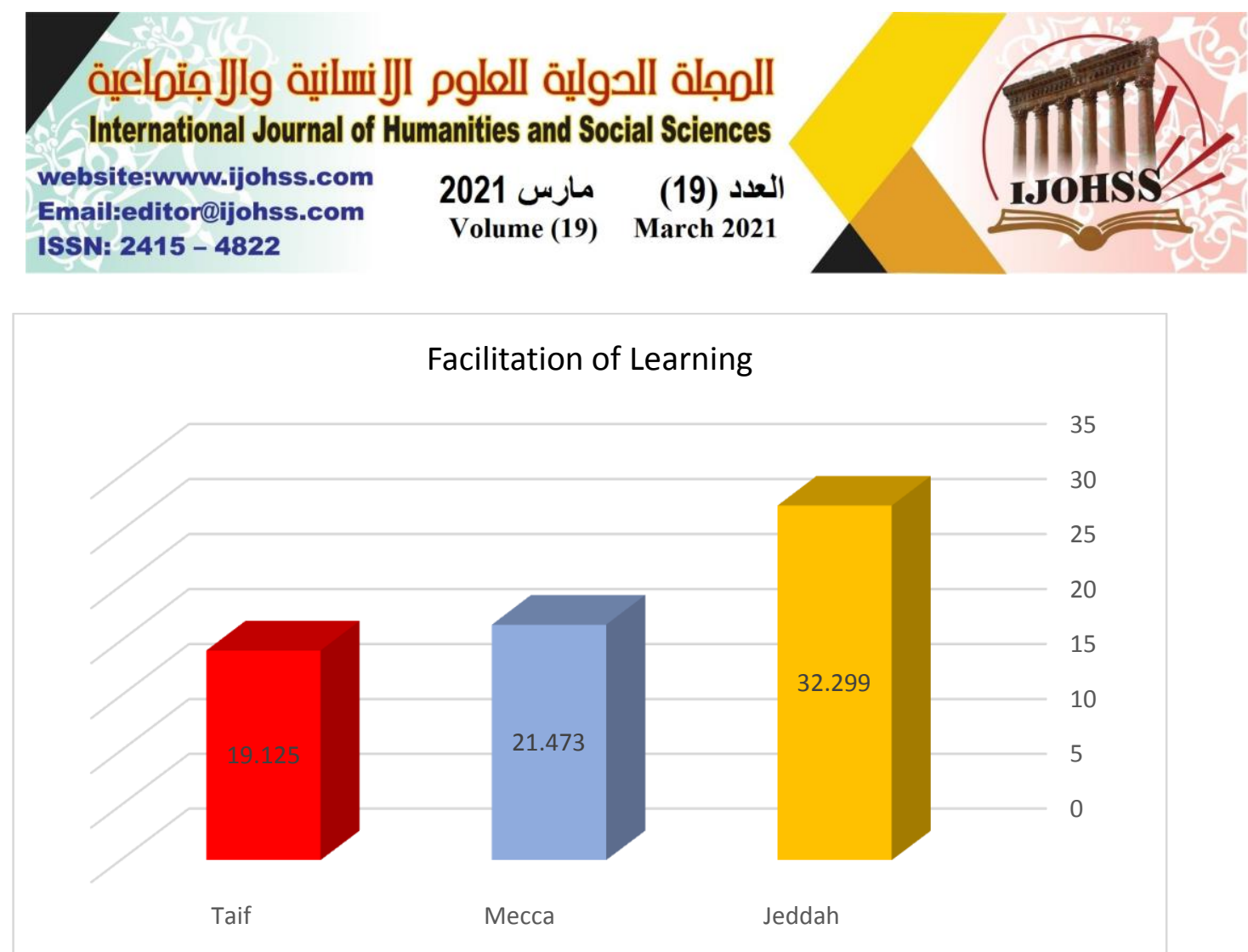

Figure 6. Score differences in Quality of Toddlers Classroom Environment In "Jeddah, Mecca, and Taif", according to Facilitation of Learning variable

It is evident from the table (14) and the figure (6) that there are differences in Facilitation of Learning between Jeddah and both Taif and Mecca in favor of Jeddah at a significance level (0.01), while there are differences between Mecca and Taif in favor of Mecca at a significance level (0.05), where the average Jeddah's score (32.299), followed by Mecca with an average (21.473), followed by Taif with an average (19.125), so Jeddah comes first, then Mecca in second place, finally Taif in last place.

\section{Parent Involvement}

In regard to Parent Involvement variable, there are statistically significant differences between the mean scores in the Quality of Toddlers Classroom Environment in the cities of Jeddah, Mecca and Taif. To verify this hypothesis, ANOVA were calculated to the mean scores in the Quality of Toddlers Classroom Environment in Jeddah, Mecca, Taif, according to Parent Involvement variable, and the following tables illustrate that.

Table 15.

Analysis of variance of mean scores in Quality of Toddlers Classroom Environment in "Jeddah, Mecca, and Taif" according to Parent Involvement variable

\begin{tabular}{l|l|l|l|l|l}
\hline Parent Involvement & $\begin{array}{l}\text { Sum of } \\
\text { Squares }\end{array}$ & Mean Square & Df & F & Sig \\
\hline Between Groups & 3064.257 & 1532.128 & 2 & 51.292 & 0.01 \\
\hline Within Groups & 2897.431 & 29.870 & 97 & & \\
\hline
\end{tabular}




\section{المجلة الحولية اللعلوم الأنسانية والإمتماعية International Journal of Humanities and Social Sciences}

website:www.ijohss.com

Email:editor@ijohss.com

ISSN: $2415-4822$ $\begin{array}{lr}2021 & \text { (19) مارس } 2021 \\ \text { Volume (19) }\end{array}$

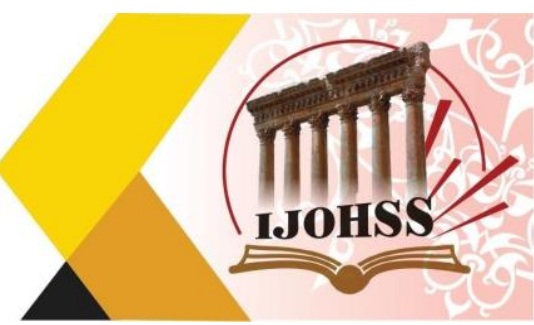

Total 5961.688 99

As illustrated in table (15), that the value of $(\mathrm{F})$ was (51.292), which is a statistically significant value at the level of (0.01), indicating that there are differences between the degrees in the Quality of Toddlers Classroom Environment in the cities Jeddah, Mecca, and Taif according to Parent Involvement variable, and to find out the significance trend, Scheffe's test was applied for multiple comparisons. The following table shows that.

Table 16.

Scheffe's test for multiple comparisons

\begin{tabular}{|c|c|c|c|}
\hline Parent Involvement & $\begin{array}{l}\text { Jeddah } \\
\mathrm{M}=8.872\end{array}$ & $\begin{array}{l}\text { Mecca } \\
M=5.193\end{array}$ & $\begin{array}{l}\text { Taif } \\
M=3.009\end{array}$ \\
\hline Jeddah & - & & \\
\hline Mecca & $* * 3.679$ & - & \\
\hline Taif & $* * 5.863$ & $* 2.184$ & - \\
\hline
\end{tabular}

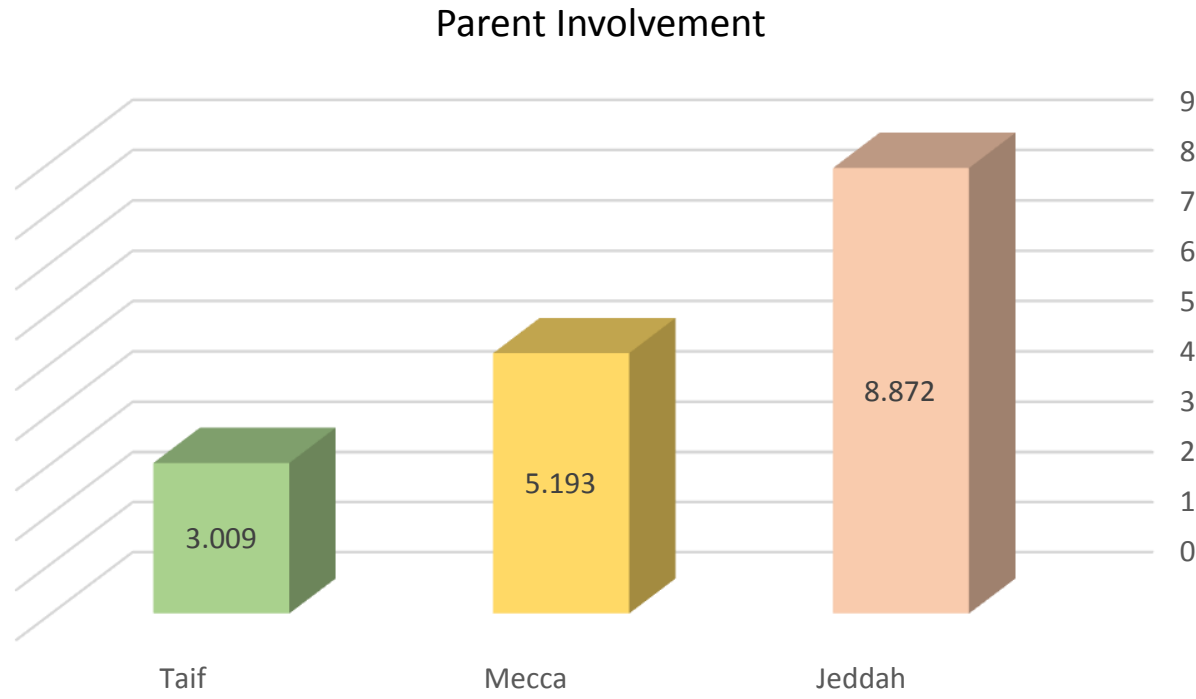

Figure 7. Score differences in Quality of Toddlers Classroom Environment In "Jeddah, Mecca, and Taif", according to Parent Involvement variable

Highlighting significant data in a table (16) and the figure (7) that there are differences in Parent Involvement between Jeddah and both Taif and Mecca in favor of Jeddah at a significance level (0.01), while there are differences between Mecca and Taif in favor of Mecca at a significance level (0.05), where the average score is Jeddah (8.872), followed by Mecca with an average (5.193), followed by Taif with an 


\section{المجلة اللدولية اللملوم الآسانية والإمتماعية International Journal of Humanities and Social Sciences}

website:www.ijohss.com

Email:editor@ijohss.com

مارس 2021

(19) (لعدا

ISSN: $2415-4822$

Volume (19) March 2021

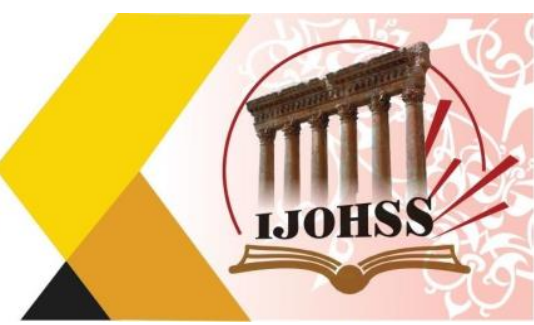

average (3.009). Therefore, according to Parent Involvement variable, the quality of toddlers' classroom environment in the city of Jeddah was higher in the rating score than the cities of Mecca and Taif.

\section{Program Structure}

In relation to program structure variable, there are statistically significant differences between the mean scores in the Quality of Toddlers Classroom Environment in the cities of Jeddah, Mecca and Taif. To verify this hypothesis, ANOVA were calculated to the mean scores in the Quality of Toddlers Classroom Environment in Jeddah, Mecca, Taif, according to Program Structure variable, and the following tables illustrate that.

\section{Table 17.}

Analysis of variance of mean scores in Quality of Toddlers Classroom Environment in "Jeddah, Mecca, and Taif" according to Program Structure variable

\begin{tabular}{l|l|l|l|l|l}
\hline Program Structure & $\begin{array}{l}\text { Sum } \\
\text { Squares }\end{array}$ & Mean Square & Df & F & Sig \\
\hline Between Groups & 2855.217 & 1427.608 & 2 & 27.220 & 0.01 \\
\hline Within Groups & 5087.359 & 52.447 & 97 & & \\
\hline Total & 7942.576 & & 99 & & \\
\hline
\end{tabular}

As shown in table 17, the value of $(\mathrm{F})$ was (27.220), which is a statistically significant value at the level of (0.01), indicating that there are differences between the degrees in the Quality of Toddlers Classroom Environment in the cities Jeddah, Mecca, and Taif in regards to program structure variable, and to find out the significance trend, Scheffe's test was applied for multiple comparisons. The following table shows that:

Table 18.

Scheffe's test for multiple comparisons

\begin{tabular}{l|l|l|l}
\hline Program Structure & Jeddah & Mecca & Taif \\
& $\mathrm{M}=24.340$ & $\mathrm{M}=22.081$ & $\mathrm{M}=19.132$ \\
\hline Jeddah & - & & \\
\hline Mecca & $* 2.259$ & - & \\
\hline Taif & $* * 5.208$ & $* 2.949$ & - \\
\hline
\end{tabular}




\section{المجلة اللحولية اللملوم الآنسانية والإمتماعية \\ International Journal of Humanities and Social Sciences}

website:www.ijohss.com

Email:editor@ijohss.com

مارس 2021

(19) (لعدا

ISSN: $2415-4822$

Volume (19) March 2021
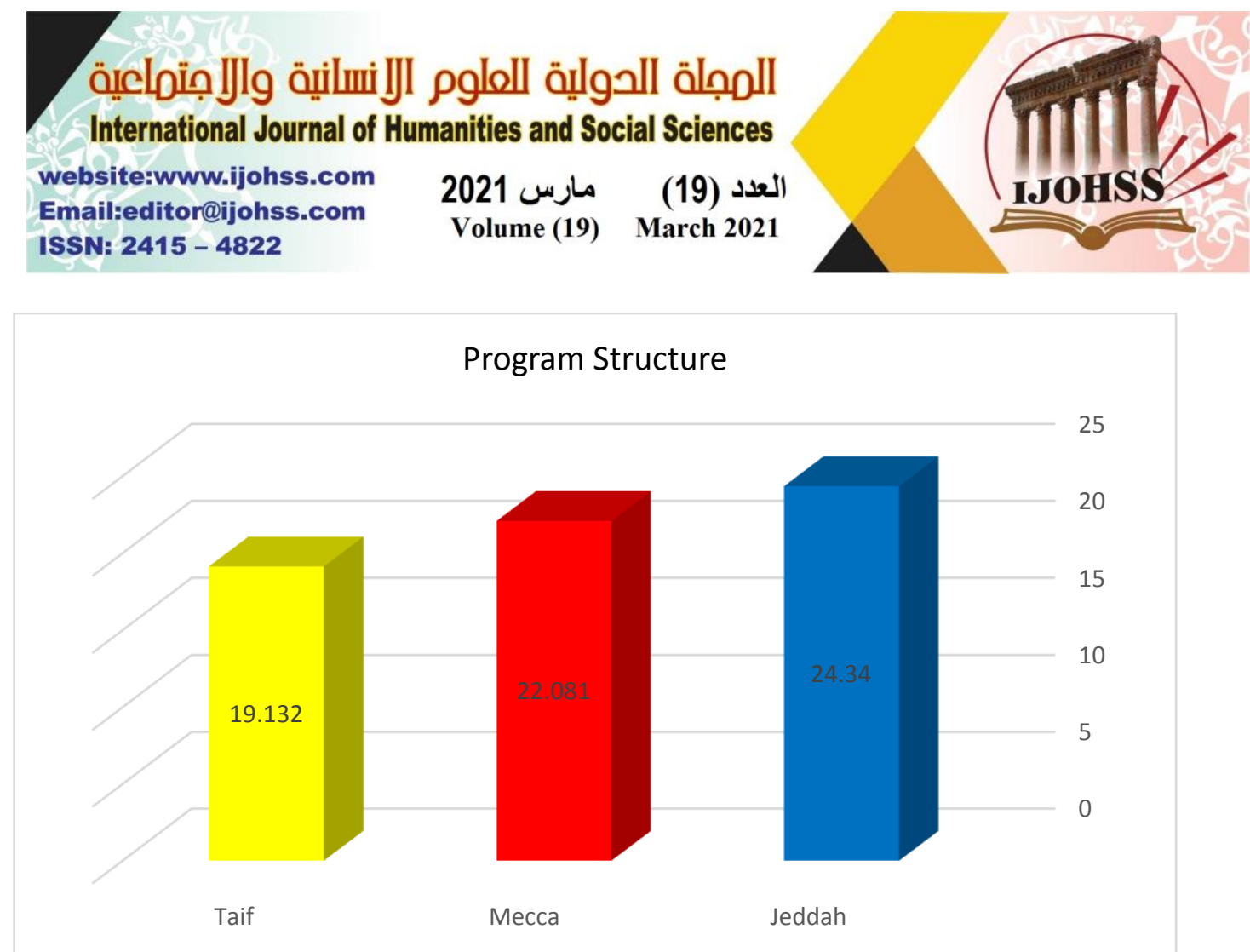

Figure 8. Score differences in Quality of Toddlers Classroom Environment In "Jeddah, mecca, and Taif", according to Program Structure variable

It is apparent from table (18) and figure (8) above that there are differences in Program Structure between Jeddah and Mecca in favor of Jeddah at a significance level (0.05), while there are differences between Jeddah and Taif in favor of Jeddah at a significance level (0.01), while there are differences between Mecca and Taif in favor of Mecca at the level of significance. Significance (0.05), with the average score for Jeddah $(24,340)$, followed by Mecca with an average $(22,081)$, followed by Taif with an average $(19,132)$, therefore Jeddah comes first, then Mecca in second place, finally Taif in last place.

\section{Teaching Strategies GOLD (Ts Gold-Related)}

In regards to Ts Gold-Related variable, there are statistically significant differences between the mean scores in the Quality of Toddlers Classroom Environment in the cities of Jeddah, Mecca and Taif. To verify this hypothesis, ANOVA were calculated to the mean scores in the Quality of Toddlers Classroom Environment in the cities Jeddah, Mecca, and Taif, according to Ts Gold-Related variable, and the following tables illustrate that.

Table 19.

Analysis of variance of mean scores in Quality of Toddlers Classroom Environment in "Jeddah, Mecca, and Taif" according to Ts Gold-Related variable

\begin{tabular}{l|l|l|l|l|l}
\hline Ts Gold-Related & $\begin{array}{l}\text { Sum of } \\
\text { Squares }\end{array}$ & Mean Square & Df & F & Sig \\
\hline Between Groups & 3030.124 & 1515.062 & 2 & 45.878 & 0.01 \\
\hline
\end{tabular}




\section{المجلة اللدولية اللملوم الآسانية والإمتماعية}

International Journal of Humanities and Social Sciences website:www.ijohss.com Email:editor@ijohss.com مارس 2021

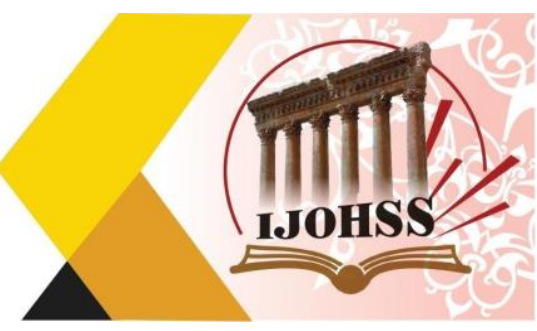

\begin{tabular}{l|l|l|l|l|l}
\hline Within Groups & 3203.274 & 33.023 & 97 & & \\
\hline Total & 6233.398 & & 99 & & \\
\hline
\end{tabular}

In addition, there is a clear differences in the score as seen in table (19) that the value of (F) was (45.878), which is a statistically significant value at the level of (0.01), indicating that there are differences between the degrees in the Quality of Toddlers Classroom Environment in the cities of Jeddah, Mecca, and Taif in relation to Ts Gold-Related variable, and to find out the significance trend, Scheffe's test was applied for multiple comparisons. The following table displays that.

Table 20.

Scheffe's test for multiple comparisons

\begin{tabular}{l|l|l|l}
\hline Ts Gold-Related & $\begin{array}{l}\text { Jeddah } \\
\mathrm{M}=16.555\end{array}$ & $\begin{array}{l}\text { Mecca } \\
\mathrm{M}=11.174\end{array}$ & $\begin{array}{l}\text { Taif } \\
\mathrm{M}=7.032\end{array}$ \\
\hline Jeddah & - & & \\
\hline Mecca & $* * 5.381$ & - & \\
\hline Taif & $* * 9.523$ & $* * 4.142$ & - \\
\hline
\end{tabular}

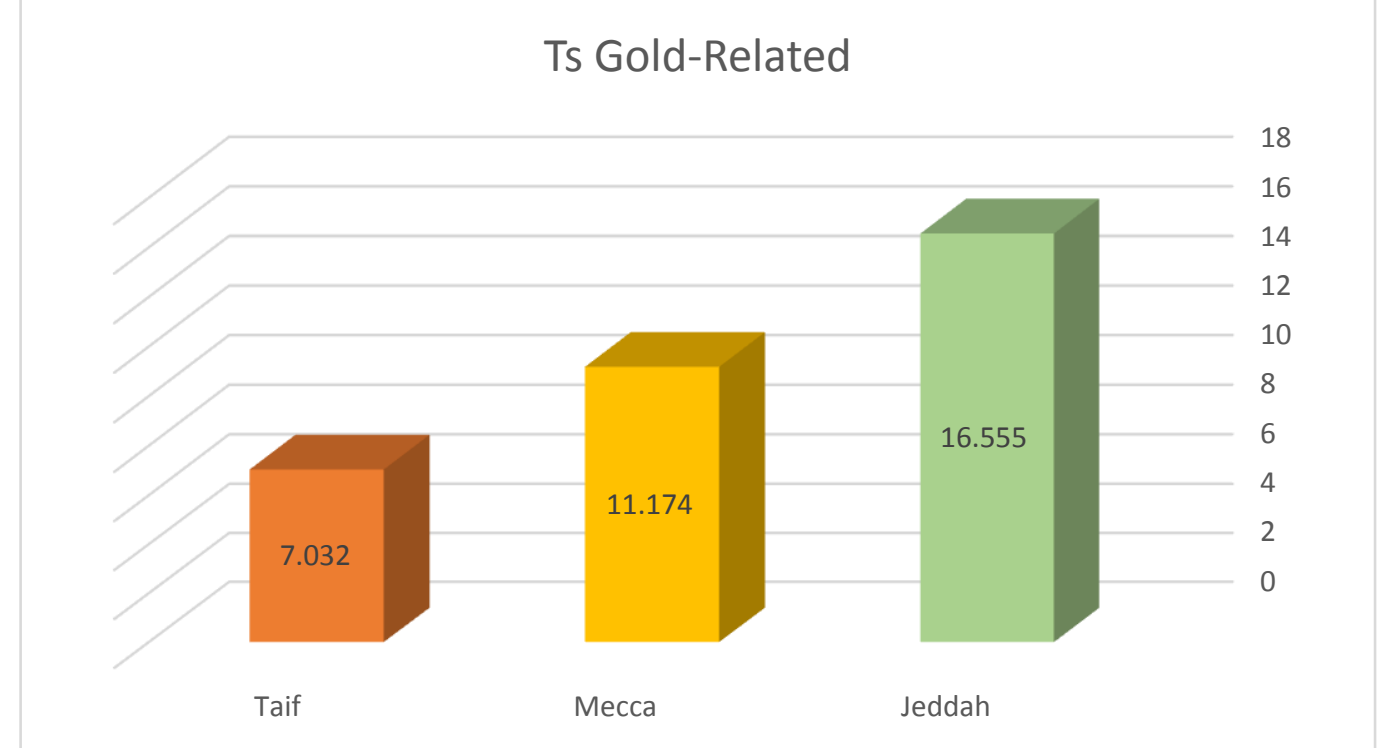

Figure 9. Score differences in Quality of Toddlers Classroom Environment In "Jeddah, Mecca, and Taif", according to Ts Gold-Related variable

As demonstrated in the table (20) and the figure (9) above, that there are differences in Ts Gold-Related between Jeddah and both of (Taif, Mecca) in favor of Jeddah at a level of significance (0.01), and there are differences between Mecca and Taif in favor of Mecca at a significant level of (0.01). The average score for Jeddah is $(16,555)$, followed by Mecca with an average $(11,174)$, followed by Taif with an 


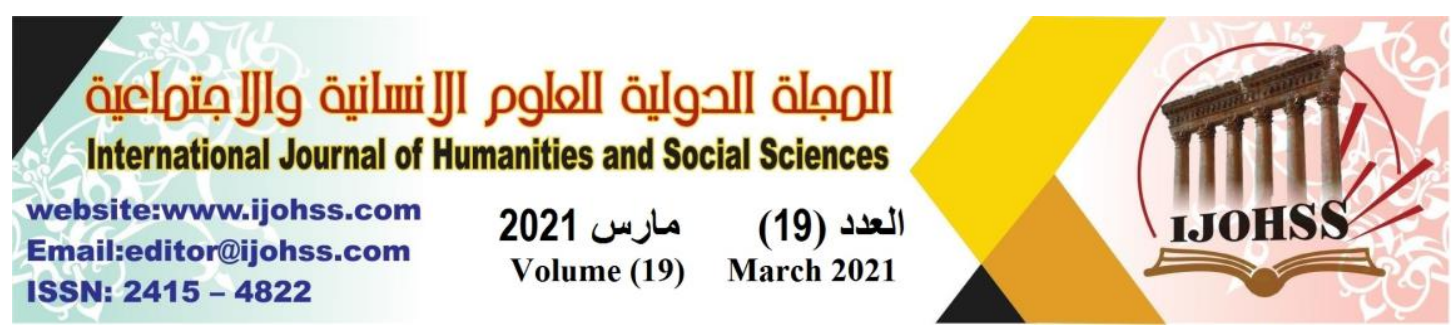

average (7.032). Consequently, the quality of toddlers' classroom environment in relation to Ts Gold-Related variable showed that the higher score of quality classroom environment in the city of Jeddah comes first, followed by the cities of Mecca and Taif.

\section{Conclusion and Recommendation}

The present study revealed several noteworthy contributions to the field of Early Childhood and its quality rating in Saudi Arabia. These included examining the quality of nine elements which are the Space and Furnishings, Daily Routines, Safety Practices, Physical Development Gross and Fine Motor, Staff Interaction, Language Modeling, Facilitation of Learning, Parent Involvement, Program Structure from Saudi mothers' perspectives. In line with previous studies in the felid, the results of the current study reflected the clear association between mothers' perspectives toward the quality of child care services and the child care centres attaining better quality standards. The main results from this study revealed that high quality early childhood education and environment will reinforce better child learning outcomes for young children. As it can be noted that there were obvious differences in the rating scores between the quality of toddlers' classroom environment in the cities of Jeddah, Mecca, and Taif from the mothers' perspectives.

The results showed that the toddlers' classroom environment in the city of Jeddah tended to have slightly higher total scores compared to the cities of Mecca and Taif in regard to the space and furnishing, physical development gross and fine motor, and parents' involvement. Additionally, there was slight differences in the quality rating score between those cities in term of the daily routines and program structure, staff interaction, language and modelling. The generated data in the current research showed that there was nearly no association of toddlers' classroom environment quality standards and children's developmental status. Nevertheless, longitudinal research is need to confirm the analytical validity of reported toddlers' childcare quality. It can be recommended that it is vital that families understand the ageappropriate assessment standards for the quality of early childhood centres and its purpose to enhance children learning and development in order to achieve equity and excellence for all of toddlers. It can be recommended that educators and policy makers should establish cultural appropriate measures to make sure that all children are assessed equally within their cultural context.

\section{References}

1. Ackerman, D.J. (2004). States' efforts in improving the qualifications of early care and education teachers. Educational Policy, 18 (2), 311-337.

2. Aguiar, C., \& McWilliam, R. A. (2013). Consistency of toddler engagement across two settings. Early Childhood Research Quarterly, 28(1), 102-110.

3. Barnes, J. (2001). Using observations to evaluate paid child care settings. In K. Petrogiannis \& E.C. Melhuish (Eds.), Early childhood: Care - education - development: Findings from international research (pp. 395-446). Athens: Kastaniotis (in Greek). 


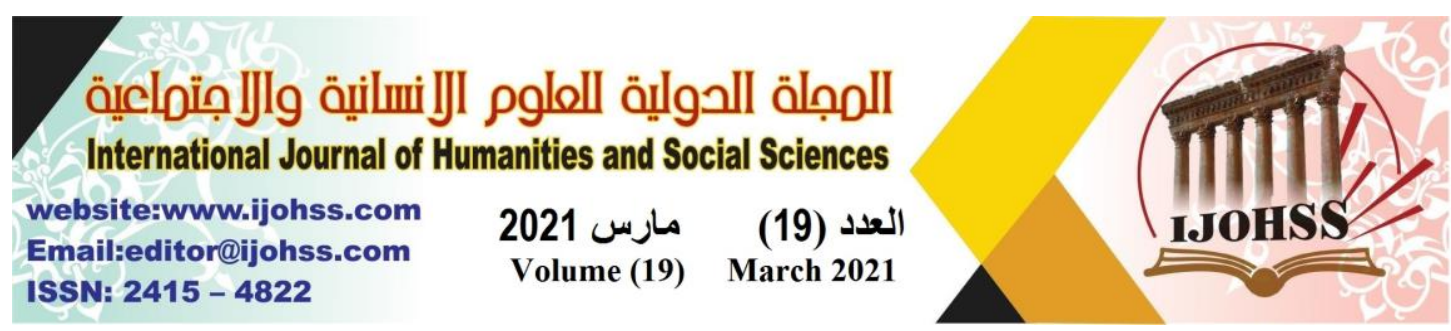

4. Bowlby, R. (2007). Babies and toddlers in non-parental daycare can avoid stress and anxiety if they develop a lasting secondary attachment bond with one carer who is consistently accessible to them. Attachment \& Human Development, 9(4), 307-19.

5. Brazelton, T. B., \& Greenspan, S. (2000). The irreducible needs of children: What every child $\backslash$ must have to grow, learn, and flourish. Cambridge, MA: Perseus Books.

6. Bronson, M.B. (2001). Self-regulation in early childhood: Nature and nurture. New York, NY: Guilford Press.

7. Burchinal, M. (2017). Measuring early care and education quality. Child Development Perspectives. Retrieved from http://dx.doi.org/10.1111/cdep.12260

8. Burchinal MR, Roberts JE, Riggins R, Zeisel SA, Neebe, E., \& Bryant, D. (2000). Relating quality of center-based child care to early cognitive and language development longitudinally. Child Development ,71(2),338-357.

9. Center on the Developing Child at Harvard University. (2006). Early exposure to toxic substances damages brain architecture, Working Paper No. 4. Retrieved from http://www.developingchild.net/pubs/wp/Early_Exposure_Toxic_Substances_Brain_Arch itecture.pdf

10. Copple, C., \& Bredekamp, S. (Eds.). (2009). Developmentally appropriate practice in early childhood programs serving children from birth through age 8 (3rd ed.). Washington, DC: National Association for the Education of young Children.

11. Denny, JH., Hallam, R., \& Homer, K. (2012). A multi-instrument examination of preschool classroom quality and the relationship between program, classroom, and teacher characteristics. Early Education and Development, 23 (5),678-696.

12. Duncan, G. J. (2003). Modeling the impacts of child care quality on children's preschool cognitive development. Child Development, 74(5), 1454-75.

13. Early, D., Maxwell, K., Burchinal, M., Alva, S., Bender, R., Bryant, D. (2007). Teachers' education, classroom quality, and young children's academic skills: Results from seven studies of preschool programs. Child Development, 78, 558-580.

14. Edwards, C. P., \& Raikes, H. (2002). Extending the dance: Relationship-based approaches to Infant-toddler care and education. Baltimore, MD: Brookes Publishing.

15. Goleman, D. (2006). Social intelligence: The new science of human relationships. New York, NY: Bantam Dell.

16. Gahwaji, N. (2006). Designing a Tool for Evaluating the Quality of Preschool Education in Saudi Arabia. Ph.D. Degree thesis, College of Education and Lifelong Learning, University of Exeter, UK.

17. Gahwaji, N. (2006). Quality of Saudi Nurseries: Application of the Translated Infants and Toddlers Evaluation Rating Scale-Third Edition (ITERS-3). Quality of Saudi Nurseries: Application of the Translated Infants and Toddlers Evaluation Rating Scale Third Edition (ITERS-3). London Journals Press, 17 (9),39-54.

18. Harms, T., Cryer, D., \& Clifford, R. M. (2006). Infant/toddler environment rating scale, revised edition, updated. New York: Teachers College Press.

19. Hawley, T. (2000). Starting smart: How early experiences affect brain development. Washington, DC: Ounce of Prevention Fund and ZERO TO THREE. Retrieved from http://main.zerotothree.org/site/DocServer/startingsmart.pdf?docID=2422. 


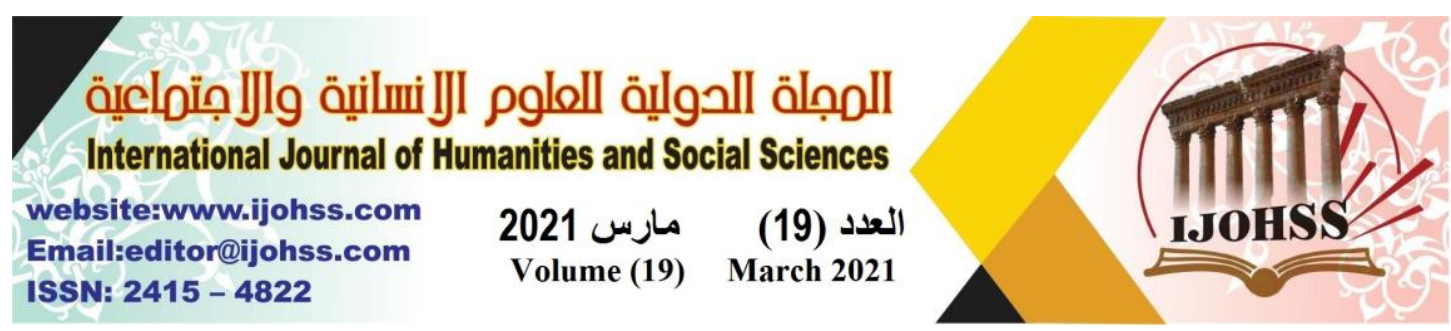

20. Hestenes, L. L., Kintner-Duffy, V., Wang, Y. C., La Paro, K., Mims, S. U., Crosby, D., Cassidy, D. J. (2015). Comparisons among quality measures in child care settings: Understanding the use of multiple measures in North Carolina's QRIS and their links to social-emotional development in preschool children. Early Childhood Research Quarterly, 30,199-214.

21. Howes, C., Burchinal, M., Pianta, R., Pianta, D., Bryant, D., Early, R., Clifford, \& Barbarin, O. (2008). Ready to learn? Children's pre-academic achievement in prekindergarten programs. Early Childhood Research Quarterly, 23(1).27-50.

22. Howes, C., James, J., \& Ritchie, S. (2003). Pathways to effective teaching. Early Childhood Research Quarterly, 18(1),104-120.

23. Klein, L., \& Knitzer, J. (2006). Effective preschool curricula and teaching strategies. NY:National Center for Children Living Poverty.

24. La Paro, K. M., Williamson, A. C., \& Hatfield, B. (2014). Assessing quality in toddler classrooms using the CLASS-toddler and the ITERS-R. Early Education and Development, 25(6), 1-6.

25. Lee, V., \& Hoaken, P. N. S. (2007). Cognition, emotion, and neurobiological development: mediating the relation between maltreatment and aggression. Child Maltreatment, 12, 281-298.

26. Mashburn, A. J., Pianta, R. C., Hamre, B. K., Downer, J. T., Barbarin, O. A., Bryant, D., et al. (2008). Measures of classroom quality in prekindergarten and children's development of academic, language, and social skills. Child Development, 79(3), 732-49.

27. McCartney, K., Dearing, E., Taylor, B. A., \& Bub, K. L. (2007). Quality child care supports the achievement of low-income children: Direct and indirect pathways through caregiving and the home environment. Journal of Applied Developmental Psychology, 28(5-6), 411-426.

28. Melhuish, E., Ereky-Stevens, K., Petrogiannis, K., Ariescu, A., Penderi, E., Rentzou, K., Tawell, A., Leseman, P., \& Broekhuisen, P. (2015). A Review of Research on the Effects of Early Childhood Education and Care (ECEC) on Child Development. Report submitted to Brussels as part of the WP4.1 Curriculum and quality analysis impact review, CARE. Brussels: European Commission. Retrieved from http://ececcare.org/fileadmin/careproject/Publications/reports/new_version_CARE_WP4_D4_1_Re view_on_the_effects_of_ECEC.pdf.

29. Melhuish, E., Quinn, L., Sylva, K., Sammons, P., Siraj-Blatchford, I., \& Taggart, B. (2012). Preschool affects longer term literacy and numeracy: Results from a general population longitudinal study in Northern Ireland. School Effectiveness and School Improvement, 24(2),234-250.

30. Mitchell, A. (2005). Stairs steps to quality: A guide for states and communities developing quality rating systems for early care and education. Retrieved from the Early Childhood Finance website: http://www.earlychildhoodfinance.org/downloads/2005/MitchStairSteps_2005.pdf 31. Nelson, C. A., \& Bosquet, M. (2000). Neurobiology of fetal and infant development: Implications for infant mental health. In C. H. Zeanah (Ed.), Handbook of infant mental health (2nd ed., pp. 37-59). New York, NY: Guilford Press. 


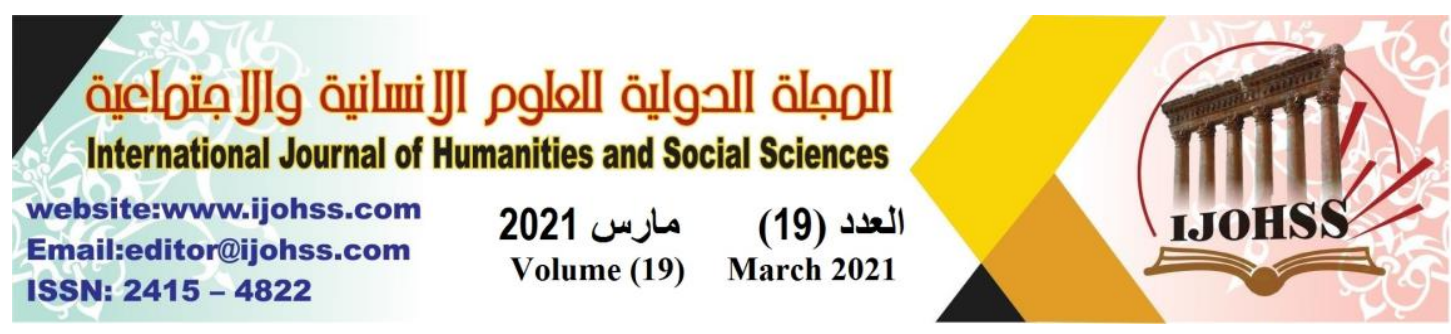

32. Peisner-Feinberg, E.S., Burchinal, M.R., Clifford, R.M., Howes, C, Kagan, S.L., Yazejian, N., Byler, P., Rustici, J., \& Zelazo, J. (1999). The children of the cost, quality, and outcomes study go to school: Technical report. Chapel Hill: University of North Carolina at Chapel Hill, Frank Porter Graham Child Development Center.

33. Pianta, R., Howes, C., \& Burchinal, M. (2005). Features of prekindergarten programs, classrooms, and teachers: do they predict observed classroom quality and child-teacher interactions? Applied Developmental Science 9(3), 144-159.

34. Qi, C.H., Kaiser, A.P., Milan, S., \& Hancock, T. (2006). Language performance of low-income African American children on the Peabody Picture Vocabulary Test-III. Language, Speech, and Hearing Services in Schools, 37, 1-12.

35. Rentzou, K., \& Sakellariou, M. (2011). The quality of early childhood educators: Children's interaction in Greek child care centers. Early Childhood Education Journal, 38(5), $367-376$.

36. Rodriguez, E., Tamis-LeMonda, C., Spellman, M., Pan, B., Lugo-Gil, Julieta, Raikes, H.H., and Luze, G. (2009). The formative role of children's literacy experiences across the first three years of life. Journal of Applied Developmental Psychology, 30, 677-694.

37. Sabol, T. J., \& Pianta, R. C. (2012). Patterns of school readiness forecast achievement and socioemotional development at the end of elementary school. Child Development, 83(1), 282-299.

38. Snow, C. E., \& Van Hemel, S. B. (Eds.). (2008). Early childhood assessment: Why, what, and how? Report of the National Research Council of the National Academies. Retrieved from http://www.nap.edu/catalog/12446.html

39. Sylva, K., Melhuish, E. C., Sammons, P., Siraj-Blatchford, I., \& Taggart, B. (2010). Early childhood matters: Evidence from the effective pre-school and primary education project. Oxford: Routledge.

40. Watamura, S. E., Phillips, D., Morrissey, T. W., McCartney, K., \& Bub, K. (2011). Double jeopardy: Poorer social-emotional outcomes for children in the NICHD SECCYD experiencing home and child-care environments that confer risk. Child Development, 82 (1), 48-65.

41. Yazejian, N., \& Bryant, D.M. (2010). Promising early returns: Educare implementation study data. Chapel Hill: FPG: Child Development Institute, UNC-CH. 